\title{
Effect of hydroxyurea on G gamma chain fetal hemoglobin synthesis by sickle-cell disease patients
}

S.M. Teixeira,

L.C. Cortellazzi and H.Z.W. Grotto
Departamento de Patologia Clínica, Faculdade de Ciências Médicas, Universidade Estadual de Campinas, Campinas, SP, Brasil

\section{Correspondence \\ H.Z.W. Grotto \\ Departamento de Patologia Clínica \\ Faculdade de Ciências Médicas \\ UNICAMP \\ Caixa Postal 6111 \\ 13081-970 Campinas, SP \\ Brasil \\ Fax: +55-19-3788-9434 \\ E-mail: grotto@fcm.unicamp.br \\ Research supported by PIBIC/CNPq. \\ Publication supported by FAPESP \\ $\ldots \ldots \ldots \ldots \ldots \ldots$}

Received November 14, 2002 Accepted June 16, 2003

\begin{abstract}
Hydroxyurea is used for sickle-cell disease patients in order to increase fetal hemoglobin synthesis and consequently decrease the severity of pain episodes. Fetal hemoglobin, which is formed by $\gamma$ globin chains $\mathrm{A}$ and $\mathrm{G}$, is present in a constant composition throughout fetal development: about $75 \%$ of ${ }^{\mathrm{G}} \gamma$ and $25 \%$ of ${ }^{\mathrm{A}} \gamma$. In contrast, adult red cells contain about $40 \%$ of ${ }^{\mathrm{G}} \gamma$ and $60 \%$ of ${ }^{\mathrm{A}} \gamma$. In the present study, we analyzed the effect of hydroxyurea induction on the $\gamma$ chain composition of fetal hemoglobin in 31 sickle-cell disease patients treated with hydroxyurea. The control group was composed of 30 sickle-cell disease patients not treated with hydroxyurea in clinical steady state. The patients were older than 13 years and were not matched for age. All patients were seen at Hemocentro/UNICAMP and Boldrini Infantile Center, Campinas, SP, Brazil. The levels of total hemoglobin were significantly higher in patients treated with hydroxyurea (mean $\pm \mathrm{SD}, 9.6 \pm 2.16 \mathrm{~g} / \mathrm{dl}$ ) than in untreated patients $(8.07 \pm 0.91 \mathrm{~g} / \mathrm{dl})$. Fetal hemoglobin levels were also higher in treated patients $(14.16 \pm 8.31 \%)$ than in untreated patients $(8.8 \pm 4.09 \%)$, as was the ${ }^{\mathrm{G}} \gamma / \mathrm{A} \gamma$ ratio $(1.45 \pm 0.78$ vs $0.98 \pm 0.4, \mathrm{P}<0.005)$. The increase in the ${ }^{\mathrm{G}} \gamma / \mathrm{A} \gamma$ ratio in patients treated with hydroxyurea suggests the prevalence of a pattern of fetal hemoglobin synthesis, whereas patients not treated with hydroxyurea maintain the adult pattern of fetal hemoglobin synthesis. Because no correlation was observed between the ${ }^{\mathrm{G}} \gamma /{ }^{\mathrm{A}} \gamma$ ratio and total hemoglobin or fetal hemoglobin levels, the increase in ${ }^{\mathrm{G}} \gamma$ chain synthesis may not imply a higher production of hemoglobin.
\end{abstract}

Fetal hemoglobin $(\mathrm{HbF})$ interferes with the intracellular polymerization of sickle hemoglobin and has beneficial effects on patients with sickle-cell disease (SCD) (1). On this base, several agents such as 5-azacytidine and hydroxyurea (HU), which are known to stimulate $\mathrm{HbF}$ synthesis, have been used in SCD patients to decrease the frequency and
Key words

- Gamma chain

- Fetal hemoglobin

- Hydroxyurea

- Sickle-cell disease severity of pain episodes $(2,3)$.

Previous studies showed that approximately $60 \%$ of the patients treated with $\mathrm{HU}$ responded with an increased $\mathrm{HbF}$ level and a reduction (44\%) in the annual rate of painful episodes. There was also a significant variation in the ability of patients to respond to HU. Prolonged treatment is generally re- 
quired to obtain the clinical response $(4,5)$.

$\mathrm{HbF}$ is formed by $\gamma$-globin chain A or $\mathrm{G}$ according to the amino acid at the 136 position in the $\gamma$ chain, i.e., alanine or glycine. The proportion of ${ }^{\mathrm{G}} \gamma$ to ${ }^{\mathrm{A}} \gamma$ is constant throughout fetal development: about $75 \%$ of ${ }^{\mathrm{G}} \gamma$ and $25 \%$ of ${ }^{\mathrm{A}} \gamma$. However, in adult red cells, the small amount of $\mathrm{HbF}$ is composed mainly of ${ }^{\mathrm{A}} \gamma$ $\left(60 \%\right.$ vs $40 \%$ of $\left.{ }^{\mathrm{G}} \gamma\right)(6)$.

Sickle-cell anemia patients present different levels of $\mathrm{HbF}$ and a relation of $\mathrm{HbF}$ and ${ }^{\mathrm{G}} \gamma$ levels with the $\beta^{\mathrm{S}}$ haplotypes has been demonstrated. Senegal and Benin haplotypes

Table 1. Hemoglobin, fetal hemoglobin and ${ }^{G} \gamma / A_{\gamma}$ ratio in sickle-cell disease (SCD) patients treated with hydroxyurea (HU) (group 1) and in SCD patients not treated with HU (group 2).

\begin{tabular}{lcccc}
\hline Variable & Mean $\pm \mathrm{SD}$ & Median & Range \\
\hline Hemoglobin (g/dl) & & & \\
Group 1 & $9.6 \pm 2.16^{*}$ & 9.5 & $5.3-16.2$ \\
Group 2 & $8.07 \pm 0.91$ & 8.05 & $6.6-11.1$ \\
& & & \\
Fetal hemoglobin (\%) & & & \\
Group 1 & $14.16 \pm 8.31^{*}$ & 12.4 & $1.0-30.8$ \\
Group 2 & $8.8 \pm 4.09$ & 8.4 & $2.9-19.8$ \\
G/A $\gamma$ & & & & \\
Group 1 & $1.45 \pm 0.78^{*}$ & 1.17 & $0.48-3.25$ \\
Group 2 & $0.98 \pm 0.4$ & 0.87 & $0.47-1.94$ \\
\hline
\end{tabular}

Group 1: $N=31 ;$ group 2: $N=30 .{ }^{*} P<0.05$ compared to patients not treated with HU (MannWhitney test).

Table 2. Correlation between the variables studied in sickle-cell disease (SCD) patients treated with hydroxyurea (HU) (group 1) and in SCD patients not treated with HU (group 2).

\begin{tabular}{|c|c|c|}
\hline & Group 1 & Group 2 \\
\hline \multirow[t]{2}{*}{$\mathrm{Hb}$ and $\mathrm{HbF}$} & r: 0.24632 & r: 0.44291 \\
\hline & $P: 0.1816$ & $P: 0.0142$ \\
\hline \multirow[t]{2}{*}{$\mathrm{HbF}$ and $\mathrm{G}_{\gamma} / \mathrm{A}_{\gamma}$} & r: -0.17769 & r: -0.22209 \\
\hline & P: 0.3389 & $P: 0.2382$ \\
\hline \multirow[t]{2}{*}{$\mathrm{Hb}$ and $\mathrm{G}_{\gamma / \mathrm{A}_{\gamma}}$} & r: -0.19738 & r: -0.37086 \\
\hline & $P: 0.2872$ & $P: 0.0436$ \\
\hline
\end{tabular}

$\mathrm{Hb}(\mathrm{g} / \mathrm{dl})=$ hemoglobin; $\mathrm{HbF}(\%)$ = fetal hemoglobin. differed in ${ }^{\mathrm{G}} \gamma$ expression, mean percentage of $\mathrm{HbF}$, which was higher in the Senegal than in the Benin type, while the Bantu haplotype had intermediate features (7). More recently, mRNA analysis strengthened these data. Sickle-cell anemia patients with Senegal and Saudi Arabia-India haplotypes had higher percentages of $\gamma$ mRNA than Benin, Bantu or Cameroon types (8).

Various in vitro cell culture systems have been used to study the effects of $\mathrm{HbF}$-inducing agents on $\gamma$-globin chain gene expression $(9,10)$. Xu and Zimmer (11) demonstrated the selective increase of ${ }^{\mathrm{G}} \gamma$ mRNA levels in K562 cells treated with HU. Understanding the mechanisms by which HU differentially regulates $\mathrm{HbF}$ gene expression during development may provide data about the mechanisms of action of the pharmacological agents used in SCD.

In the present study, we have determined the effect of HU induction on total $\mathrm{Hb}$ level, $\mathrm{HbF}$ level and mainly the ${ }^{\mathrm{G}} \gamma / \mathrm{A} \gamma$ ratio. In addition, we have compared the relationship between these parameters in order to establish the $\mathrm{HbF}$ synthesis patterns in patients with and without HU.

$\mathrm{HbF}$ level was determined by the alkaline $\mathrm{pH}$ denaturation method (12). In order to separate gel ${ }^{\mathrm{G}} \gamma$ and ${ }^{\mathrm{A}} \gamma, \mathrm{HbF}$ was precipitated with sulfosalicylic acid and globin chains were analyzed by polyacrylamide gel electrophoresis, followed by densitometry to determine the proportions of the two chains $(13,14)$. Patients with SCD at Hemocentro/ UNICAMP and Boldrini Infantile Center, Campinas, SP, Brazil, treated with HU (group $1, \mathrm{~N}=31$ ) were compared with a control group of SCD patients without HU (group 2, $\mathrm{N}=30$ ). Control patients were free of crises. All patients but two were older than 13 years. The duration of treatment ranged from 2 months to 5 years (mean time, 2 years).

Group 1 patients had significantly higher levels of $\mathrm{Hb}, \mathrm{HbF}$, and ${ }^{\mathrm{G}} \gamma / \mathrm{A} \gamma$ ratio than group 2 (Mann-Whitney test; Table 1).

No correlation was found between total 
$\mathrm{Hb}$ and $\mathrm{HbF}$ levels or between $\mathrm{Hb}$ levels (total and $\mathrm{HbF}$ ) and ${ }^{\mathrm{G}} \gamma / \mathrm{A} \gamma$ ratio in group 1. However, there was a positive correlation between $\mathrm{Hb}$ level and $\mathrm{HbF}$ level and a negative correlation between $\mathrm{Hb}$ level and ${ }^{\mathrm{G}} \gamma / \mathrm{A} \gamma$ ratio in group 2 (Table 2).

Several possible mechanisms have been suggested to explain the action of $\mathrm{HU}$ on $\mathrm{HbF}$ synthesis. One of them is that HU selectively increases $\mathrm{HbF}$ production because, like 5-azacytidine, it may act directly on late erythroid progenitors, reprogramming them to produce more $\mathrm{HbF}(10,15)$. An in vitro study has shown that the number of burstforming unit-erythroid colonies decreased whereas $\mathrm{HbF}$ levels increased in the presence of $\mathrm{HU}$ (16).

The present results, which are in agreement with other studies $(2,3,5)$, demonstrate that treatment with $\mathrm{HU}$ increases $\mathrm{HbF}$ levels in patients with SCD. In addition, the predominant effect of $\mathrm{HU}$ on ${ }^{\mathrm{G}} \gamma$ synthesis was evident since the ${ }^{\mathrm{G}} \gamma / \mathrm{A} \gamma$ ratio was significantly higher in the group treated with HU than in the control group. Similar results were reported by Xu and Zimmer (11) using cell culture: the ${ }^{\mathrm{G}} \gamma$ mRNA level increased 2- to 3 -fold at $168 \mathrm{~h}$, whereas the ${ }^{\mathrm{A}} \gamma$ mRNA level did not change.

The lack of correlation between $\mathrm{HbF}$ levels and ${ }^{\mathrm{G}} \gamma /{ }^{\mathrm{A}} \gamma$ ratio suggests that the return to the fetal $\gamma$ chain synthesis does not imply an absolute increase of $\mathrm{HbF}$ production. There is a wide range of factors, both genetic and acquired, that interfere with the increase in $\mathrm{HbF}$ production. Among these factors, $\mathrm{HbF}$ production can be influenced by cis-acting determinants such as $\beta$-globin haplotype and by trans-acting elements such as the X-linked "F cell" production locus. It was demonstrated that the "F cell" production locus is a more important factor in determining $\mathrm{HbF}$ levels than $\beta$-globin haplotype, $\alpha$-globin gene number, or patient age or sex (17). A placebo-controlled study of the efficacy of HU therapy in sickle-cell anemia patients showed that the Central African Republic (CAR) haplotype was associated with a reduced $\mathrm{HbF}$ production response, while patients with the highest baseline granulocyte and reticulocyte counts had the greatest increase in $\mathrm{HbF}$. These data indicate that bone marrow reserve may be an important factor in $\mathrm{HbF}$ response. The maintenance of the proliferative capacity of bone marrow in spite of the myelotoxic effects of the drugs is important to sustain $\mathrm{HbF}$ increases during $\mathrm{HU}$ treatment (18).

In the present study it was not possible to correlate $\gamma$ chain production and composition with $\beta$-globin haplotypes since haplotypes were determined in 26 of 31 treated patients and only in 10 of 30 controls. However, haplotype distribution was similar for the two groups and was divided into Benin and CAR haplotypes according to the distribution reported for the Brazilian Black population (19). A future extensive study may clarify the influence of haplotype on $\gamma$ chain production stimulated with $\mathrm{HU}$.

The predominant $\gamma$ chain synthesis induced by HU probably contributes to a milder illness in SCD patients. The contributions of ${ }^{\mathrm{A}} \gamma$ and ${ }^{\mathrm{G}} \gamma$ to the prevention of the sickling process are apparently different. The presence of an alanine $\left({ }^{\mathrm{A}} \gamma\right)$ instead of a glycine $\left({ }^{\mathrm{G}} \gamma\right)$ at position 136 of the $\gamma$ chain interferes with the interaction between $\gamma$ chain and sickle $B$ chain due to a reduced flexibility of ${ }^{\mathrm{A}} \gamma$. Thus, ${ }^{\mathrm{A}} \boldsymbol{\gamma}$ is less effective than ${ }^{\mathrm{G}} \gamma$ in preventing the polymerization of the sickle $\beta$ chain (20).

\section{Acknowledgments}

The authors are indebted to Elza M. Kimura and Sirley Gervásio (Clinical Pathology Division, HC, UNICAMP, Campinas, SP, Brazil) for technical assistance, and to Vera Suzigan for English revision. 


\section{References}

1. Roa D, Kopsombut P, Aguinaga MDP \& Turner EA (1997). Hydroxyurea-induced denaturation of normal and sickle-cell hemoglobins in vitro. Journal of Clinical Laboratory Analysis, 11: 208-213.

2. Dover GJ \& Charache S (1992). Hydroxyurea induction of fetal hemoglobin synthesis in sickle-cell disease. Seminars in Oncology, 19: 61-66

3. Lima CSP, Arruda VR, Costa FF \& Saad STO (1997). Minimal doses of hydroxyurea for sickle-cell disease. Brazilian Journal of Medical and Biological Research, 30: 933-940.

4. Charache S, Dover GJ, Moore RD et al. (1992). Hydroxyurea: effects on hemoglobin $\mathrm{F}$ production in patients with sickle-cell anemia. Blood, 79: 2555-2565.

5. Rodgers GP, Dover GJ, Noguchi CT, Schechter AN \& Nienhuis AW (1990). Hematologic responses of patients with sickle-cell disease to treatment with hydroxyurea. New England Journal of Medicine, 322: 1037-1045

6. Jensen M, Attemberg H, Schneider CH \& Walter JU (1982). The developmental change in the $\gamma \mathrm{G}$ and $\gamma \mathrm{A}$ globin proportions in hemoglobin F. European Journal of Pediatrics, 138: 311-314.

7. Nagel RL, Rao SK, Dunda-Belkhodja O, Connolly MM, Fabry ME, Geeorges A, Krishnamoorthy R \& Labie D (1987). The hematologic characteristics of sickle-cell anemia bearing the Bantu haplotype: the relationship between G gamma and HbF level. Blood, 69: 10261030 .

8. Smetanina NS, Gu L-H \& Huisman THJ (1998). Comparison of the relative quantities of $\gamma$-mRNAs and fetal hemoglobin in SS patients with different haplotypes. Acta Haematologica, 100: 4-8.

9. Fibach E, Prasanna P, Rodger GP \& Samid D (1993). Enhanced fetal hemoglobin production by phenylacetate and 4-phenylbutyrate in erythroid precursors derived from normal donors and patients with sickle-cell anemia and beta thalassemia. Blood, 82: 2203-2209.

10. Humphries RK, Dover GJ, Young NS, Moore JG, Charache S, Ley T \& Nienhuis AW (1985). 5-Azacytidine acts directly on both erythroid precursors and progenitors to increase production of fetal hemoglobin. Journal of Clinical Investigation, 75: 547-557.

11. Xu J \& Zimmer DB (1998). Differential regulation of A gamma and G gamma fetal hemoglobin mRNA levels by hydroxyurea and butyrate. Experimental Hematology, 26: 265-272.

12. Pembrey ME, MacWade P \& Weatherall DJ (1972). Reliable routine estimation of small amounts of foetal hemoglobin by alkali denaturation. Journal of Clinical Pathology, 25: 738-740.

13. Villalobos-Arámbula AR, Aguilar-Luna JC, Esparza A, Perea FJ, de Loza R, Hernández-Córdova A \& Ibarra B (1993). Hemoglobina fetal y relación de cadenas $\gamma^{\mathrm{G}} / \gamma^{\mathrm{A}}$ em niños com leucemia aguda linfoblástica L1 y L2. Sangre, 38: 31-35.

14. Alter BP, Goff SC, Efremov GD, Gravely ME \& Huisman THJ (1980). Globin chain electrophoresis: a new approach to the determination of the ${ }^{G} \gamma /{ }^{A} \gamma$ ratio in fetal haemoglobin and to studies of globin synthesis. British Journal of Haematology, 44: 527-534

15. Dover GJ, Humphries RK, Moore JG, Ley TJ, Young NS, Charache S \& Nienhuis AW (1986). Hydroxyurea induction of hemoglobin F production in sickle-cell disease: relationship between cytotoxicity and $\mathrm{F}$ cell production. Blood, 67: 735-738

16. Yang YM, Pace B, Kitchens D, Ballas SK, Shah A \& Baliga BS (1997). BFU-E colony growth in response to hydroxyurea: correlation between in vitro and in vivo fetal hemoglobin induction. American Journal of Hematology, 56: 252-258.

17. Chang YC, Smith KD, Moore RD, Serjeant GR \& Dover GJ (1995). An analysis of fetal hemoglobin variation in sickle-cell disease: the relative contributions of the X-linked factor, $\beta$-globin haplotypes, $\alpha$ globin gene number, gender, and age. Blood, 85: 1111-1117.

18. Steinberg MH, Lu Z-H, Barton FB, Terrin ML, Charache S, Dover GJ \& Multicenter Study of Hydroxyurea (1997). Fetal hemoglobin in sickle-cell anemia: determinants of response to hydroxyurea. Blood, 89: 1078-1088.

19. Zago MA, Figueiredo MS \& Ogo SH (1992). Bantu $ß^{S}$ cluster haplotype predominates among Brazilian blacks. American Journal of Physical Anthropology, 88: 295-298.

20. Bhaumik K (1994). Fetal hemoglobin synthesis in sickle cell anemia: some molecular considerations. American Journal of Hematology, 46: 101-106. 